\title{
PENINGKATAN KINERJA GURU MELALUI KEGIATAN PELATIHAN PENYUSUNAN PROPOSAL PENELITIAN TINDAKAN KELAS (PTK) (STUDI KASUS PADA GURU-GURU EKONOMI DI KABUPATEN MALANG)
}

\author{
Sri Handayani ${ }^{1}$, Nasikh $^{2}$, Annisya' ${ }^{3}$ \\ 1. Economic Education Program, Faculty of Economics, State University Malang \\ 2. Economic Education Program, Faculty of Economics, State University Malang \\ 3. Economic Education Program, Faculty of Economics, State University Malang \\ sri.handayani.fe@um.ac.id,nasikh.fe@um.ac.id, annisyafarfalla@gmail.com
}

\begin{abstract}
The performance of professional teachers should be owned by every educator because through these conditions can be obtained education that can form a quality human. One of the things that should be done by teachers to have professional performance must be able to prepare a Classroom Action Research Proposal (PTK). The main purpose of TOD is to improve and improve the professional services of teachers. Objectives to be achieved in this research are: 1) To improve the competence of preparing classroom action research proposal (PTK) economic teachers in Malang Regency, 2) To know the effectiveness of preparation of PTK proposal for economic teachers in Malang Regency.
\end{abstract}

Keywords: Classroom Action Research (PTK), Teacher Performance, Economics Subject.

History of Article:

Received:(19 Agustus 2017), Accepted : (19 September2017), Publised: (15 October2017)

\section{Citation:}

Handayani, Sri., Nasikh., \& Annisya' (2017) Peningkatan Kinerja Guru Melalui Kegiatan Pelatihan Penyusunan Proposal Penelitian Tindakan Kelas (PTK) (Studi Kasus Pada Guru-Guru Ekonomi di Kabupaten Malang. [Improved teacher performance through training of development classroom action research proposal (case study in economic teachers in malang regency)]. Jurnal Pendidikan Ekonomi, 10(2), 157-166.

(C) Universitas Negeri Malang 


\section{PENDAHULUAN}

Kinerja dalam pengertiannya disebut juga sebagai prestasi kerja atau dalam bahasa inggris disebut dengan performance. Kinerja merupakan hasil atau tingkat keberhasilan seseorang secara keseluruhan selama periode tertentu di dalam melaksanakan tugas dibandingkan dengan berbagai kemungkinan, seperti standar hasil kerja, target atau sasaran atau kriteria yang telah ditentukan terlebih dahulu dan telah disepakati bersama. Guru yang memiliki kinerja yang baik sering disebut sebagai guru yang profesional (Jalal \& Supriadi, 2001).

Kinerja guru yang profesional seharusnya dimiliki oleh setiap pendidik karena melalui kondisi tersebut dapat diperoleh pendidikan yang mampu membentuk manusia berkualitas. Untuk mewujudkannya dapat dilakukan dengan ketersediaan pendidik yang berkualitas. Berbagai upaya sudah dilakukan untuk menghasilkan pendidik yang memiliki kinerja berkualitas. Salah satu upaya tersebut berasal dari pemerintah dengan menetapkan perogram sertifikasi guru yang diatur oleh Undang-Undang RI Nomor 20 Tahun 2003 tentang Sistem Pendidikan Nasional, Undang-undang RI Nomor 14 Tahun 2005 tentang Guru dan Dosen, dan Peraturan Pemerintah RI Nomor 19 Tahun 2005 tentang Standar Nasional Pendidikan menyatakan guru adalah pendidik profesional.

Dalam UU No.14/2005 Pasal 7 menyatakan bahwa profesi guru dan profesi dosen merupakan bidang pekerjaan khusus yang dilaksanakan berdasarkan prinsip profesionalisme. Dari beberapa prinsip profesionalisme ada salah satu yang perlu dicermati yaitu bahwa pendidik harus memiliki kompetensi yang diperlukan sesuai dengan bidang tugasnya. Untuk mengembangkan kompetensi guru ada beberapa hal yang harus dilakukan. Salah satu langkah yaitu dengan melakukan Penelitian Tindakan Kelas (PTK).

PTK dapat langsung dimanfaatkan untuk meningkatkan atau memperbaiki kualitas pembelajaran di dalam kelas guru yang bersangkutan. Penelitian Tindakan Kelas (PTK) tersebut memiliki tujuan yaitu untuk memperbaiki atau meningkatkan praktik pembelajaran secara berkesinambungan yang pada dasarnya melekat penunaian misi profesional kependidikan yang diemban oleh guru. Dengan kata lain, tujuan utama PTK adalah untuk perbaikan dan peningkatan layanan profesional guru. Di samping itu, sebagai tujuan PTK adalah untuk meningkatkan budaya meneliti bagi guru (Widayati, 2012).

Seperti yang telah dijelaskan oleh Widayati (2012) bahwasannya PTK nantinya diharapkan meningkatkan kompetensi guru. Kompetensi ini perlu dilaksanakan secara sadar dan sistematik di kelas. Menurut penjelasan Sukanti (2008, pp. 1-11) bahwasannya tidak semua kompetensi dapat ditingkatkan oleh seorang tetapi hanya subkompetensi tertentu saja seperti: (1) memahami gaya belajar dan kesulitan belajar peserta didik, (2) menguasai teori dan prinsip belajar serta pembelajaran yang mendidik, (3) mengembangkan kurikulum yang mendorong keterlibatan peserta didik dalam pembelajaran, (4) merancang pembelajaran yang mendidik, (5) melaksanakan pembelajaran yang mendidik, (6) mengevaluasi proses dan hasil pembelajaran, (7) mengevaluasi kinerja sendiri, (8) mengembangkan diri secara berkelanjutan, (9) menguasai substansi bidang studi dan metodologi keilmuannya, (10) menguasai struktur bidang studi dan materi kurikulum bidang studi, (11) menguasai dan memanfaatkan teknologi informasi dan komunikasi dalam pembelajaran, (12) mengorganisasikan materi kurikulum bidang studi, (13) meningkatkan kualitas pembelajaran. 
Sebagai seorang guru dalam melakukan proses belajar mengajar tentunya ada kendala atau masalah yang dihadapi. Upaya yang dapat dilakukan dalam mengatasi permasalahan proses kegiatan mengajar dapat dilakukan dengan melakukan Penelitian Tindakan Kelas (PTK). Dengan melakukan penelitian tindakan guru dapat segera mengidentifikasi penyebab faktor-faktor yang dapat menimbulkan permasalahan dan segera dapat menemukan solusi dari tindakan yang diterapkan. Di kabupaten malang dengan luas area yang sangat luas dan guru yang relatif cukup banyak tentunya sangat potensial untuk melakukan penelitian tindakan kelas.

Tujuan utama dari kegiatan ini adalah untuk meningkatkan kemampuan guru-guru Ekonomi dalam bidang Penelitian terutama Penelitian Tindakan Kelas (PTK) dalam proses pembelajaran di Kabupaten Malang. Manfaat yang diharapkan dari kegiatan ini adalah: (1) Bisa membuat laporan-laporan PTK yang dapat dijadikan bahan panduan bagi para pendidik (guru) untuk meningkatkan kulitas pembelajaran. Selain itu hasil-hasil PTK yang dilaporkan dapat dijadikan sebagai bahan artikel ilmiah atau makalah untuk berbagai kepentingan antara lain disajikan dalam forum ilmiah dan dimuat di jurnal ilmiah, (2) Menumbuhkembangkan kebiasaan, budaya, dan atau tradisi meneliti dan menulis artikel ilmiah di kalangan pendidik. Hal ini ikut mendukung professionalisme dan karir pendidik, (3) Mewujudkan kerja sama, kaloborasi, dan atau sinergi antarpendidik dalam satu sekolah atau beberapa sekolah untuk bersama-sama memecahkan masalah dalam pembelajaran dan meningkatkan mutu pembelajaran, (4) Meningkatkan kemampuan pendidik dalam upaya menjabarkan kurikulum atau program pembelajaran sesuai dengan tuntutan dan konteks lokal, sekolah, dan kelas. Hal ini turut memperkuat relevansi pembelajaran bagi kebutuhan peserta didik, (5) Memupuk dan meningkatkan keterlibatan, kegairahan, keter-tarikan, kenyamanan, dan kesenangan siswa dalam mengikuti proses pembelajaran di kelas. Di samping itu, hasil belajar siswa pun dapat meningkat, (6) Mendorong terwujudnya proses pembelajaran yang menarik, menantang, nyaman, menyenangkan, serta melibatkan siswa karena strategi, metode, teknik, dan atau media yang digunakan dalam pembelajaran demikian bervariasi dan dipilih secara sungguh-sungguh.

Berdasarkan paparan di atas maka perlu dilakukan penelitian dengan judul "Peningkatan Kinerja Guru Melalui Kegiatan Pelatihan Penyusunan Proposal Penelitian Tindakan Kelas (PTK) bagi Guru-guru Ekonomi di Kabupaten Malang”.

\section{METODE PENELITIAN}

Penelitian ini merupakan penelitian kualitatif, dengan tujuan agar dapat memperoleh pemahaman dan penafsiran mendalam tentang makna dari fenomena yang ada di lapangan. Pendekatan kualitatif adalah suatu proses penelitian dan pemahaman yang berdasarkan pada metodologi yang menyelidiki suatu fenomena sosial dan masalah manusia. Pada pendekatan ini, peneliti membuat suatu gambaran kompleks, meneliti kata-kata, laporan terinci dari pandangan responden, dan melakukan studi pada situasi yang alami (Creswell, 2015:p.15).

Sedangkan sifat atau kategori dalam penelitian ini merupakan penelitian evaluasi menggunakan metodologi studi kasus (case studies). Studi kasus bertujuan untuk: (1) menghasilkan deskripsi detail dari suatu fenomena; (2) mengembangkan 
penjelasan-penjelasan yang dapat diberikan dari suatu studi kasus itu; (3) mengevalusi fenomena-fenomena.

Penelitian studi kasus adalah studi yang mengeksplorasi suatu masalah dengan batasan terperinci, memiliki pengambilan data yang mendalam, dan menyertakan berbagai sumber informasi. Penelitian ini dibatasi oleh waktu dan tempat, dan kasus yang dipelajari berupa program, peristiwa, aktivitas, atau individu.

\section{Lokasi Penelitian}

Lokasi penelitian dalam penelitian ini adalah SMA Negeri di Kabupaten Malang yang diwadahi oleh Organisasi Profesi Guru yaitu MGMP (Musyawarah Guru Mata Pelajaran) Ekonomi. Dalam kegiatan ini bertempat di SMAN 1 Kepanjen Kabupaten Malang.

\section{Sumber Data}

Informan

Sumber data dalam penelitian ini berasal dari para informan yakni para Guru ekonomi SMA Negeri dan Swasta di Kabupaten Malang yang tergabung sebagai anggota MGMP Kabupaten Malang. Dengan jumlah populasi 35 orang. Populasi tersebut sebagai informan awal dalam rangkaian penelitian, sedangkan tahap berikutnya dari populasi tersebut diambil informan yang mewakili sebagai informan kunci dalam tahap penelitian selanjutnya, yang diperoleh melalui survey awal tersebut (melalui pemberian instrument) dan tahap penelitian yang kedua (melalui pemberian instrument).

Dari data tersebut ditentukan lima (5) orang informan sebagai informan kunci dari hasil survey awal dan pemberian kuesioner pada tahap penelitian awal, yang terdiri dari 35 orang guru ekonomi yang ada di Kabupaten Malang. Kriteria penentuan informan berdasarkan senioritas, lama mengajar ekonomi, tingkat pendidikan, dan pengalaman tambahan selama menjadi guru baik sebelum sertifikasi maupun sesudah sertifikasi.

Dokumen

Selain itu data dalam penelitian ini diperoleh melalui dokumen,yaitu dokumen yang diperoleh melalui guru berupa proposal PTK dan dokumentasi dalam proses wawancara dan pengamatan.

\section{Metode Pengumpulan Data Observasi}

Dalam penelitian ini observasi adalah metode pengumpulan data yang digunakan untuk menghimpun data penelitian melalui pengamatan dan penginderaan. Suatu kegiatan pengamatan baru dikategorikan sebagai kegiatan pengumpulan data penelitian apabila memiliki kriteria sebagai berikut:

a) Pengamatan digunakan dalam penelitian dan telah direncanakan secara serius

b) Pengamatan harus berkaitan dengan tujuan penelitian yang telah ditetapkan 
c) Pengamatan dicatat secara sistematis dan dihubugkan dengan proposisi umum dan bukan dipaparkan sebagai suatu yang hanya menarik perhatian

d) Pengamatan dapat dicek dan dikontrol mengenai keabsahannya.

Hal-hal yang perlu diperhatikan dalam melakukan observasi:

a) Hal-hal apa yang hendak diamati

b) Bagaimana mencatat pengamatan

c) Alat bantu pengamatan

d) Bagaimana mengatur jarak pengamat dan objek yang diamati

\section{Kuesioner}

Dalam penelitian ini kuesio-ner digunakan untuk menggali persepsi guru ekonomi di Kota Malang tentang Kinerja Guru terutama yang berkaitan dengan melakukan penelitian dalam penyusunan Proposal PTK.

Wawancara

Dalam penelitian ini digunakan metode wawancara mendalam (in depth interview), yakni proses memperoleh keterangan untuk tujuan penelitian dengan cara Tanya jawab sambil bertatap muka antara pewawancara dengan informan atau orang yang diwawancarai.

\section{Dokumentasi}

Pada intinya metode dokumentasi adalah metode yang digunakan untuk menelusuri data historis. Dalam penelitian ini adalah data sekunder yang berasal dari literatur terkait tentang kinerja guru dalam kegiatan penelitian.

\section{Tahap Pengumpulan Data}

Dalam penelitian ini beberapa tahapan dalam proses pengumpulan data yaitu (a) survey/ observasi awal yang dilaksanakan pada bulan Februari - Maret 2017, dengan menggunakan kuesioner yang berisi latar belakang guru ekonomi SMA Negeri Kabupaten Malang, sekaligus pengenalan peneliti terhadap lapangan, (b) Penyebaran kuesioner, April 2017, untuk Kinerja Guru terutama yang berkaitan dengan melakukan penelitian dalam penyusunan Proposal PTK, (c) wawancara kepada 5 informan kunci, dilaksankan pada bulan Mei-Juni 2017 untuk menggali lebih dalam tentang persepsi guru pada pada menumbuhkan jiwa penelitian melalui kegiatan penyusunan proposal Penelitian Tindakan Kelas (PTK).

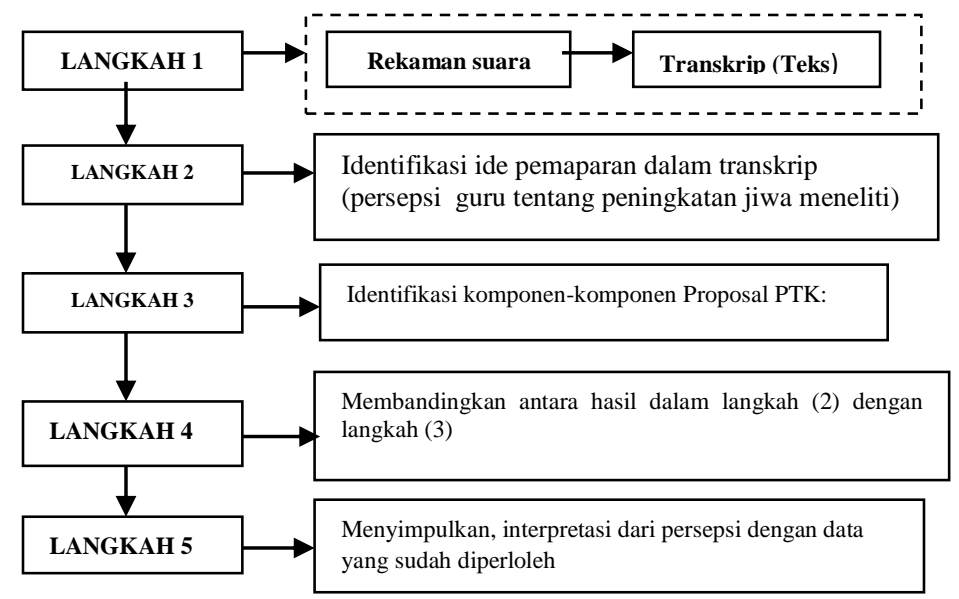




\section{Gambar 1 Langkah Analisis Data}

Pada dasarnya analisis data kualitatif menurut Bogdan dan Biklen adalah upaya yang dilakukan dengan jalan bekerja dengan data, mengorganisasikan data, memilah-milahnya menjadi satuan yang dapat dikelola, mensintesiskannya, mencari dan menemukan pola, menemukan apa yang penting dan apa yang dipelajari, dan memutuskan apa yang dapat diceritakan kepada orang lain.

\section{Pengecekan Keabsahan Data}

Pengecekan keabsahan terhadap penelitian perlu dilakukan dalam upaya memperoleh kredi-bilitas hasil penelitian antara lain;

$>$ Perpanjangan waktu pengamatan

Perpanjangan penelitian ber-makna penambahan waktu keikutsertaan di lapangan penelitian sampai dengan kejenuhan pengumpulan data benar-benar terpenuhi.

$>$ Triangulasi

Triangulasi merupakan upaya untuk melihat fenomena dari berbagai sudut, melakukan verifikasi temuan dengan menggunakan berbagai sumber informasi dan teknik.

$>$ Member check

Member check adalah pengecekan kebenaran data dengan cara mengembalikan data tersebut kepada sumber data untuk diperiksa kebenaranya. Member check dapat dilakukan setelah data rekaman di transkrip atau setelah draf laporan penelitian ini terselesaikan. Member check dimaksudkan untuk koreksi penambahan atau pengurangan data, sehingga keterbukaan dalam analisis data sangat diperlukan.

$>$ Audit trail

Audit trail merupakan pemeriksaan terhadap kesesusaian temuan penelitian dengan data lapangan, melalui pelacakan terhadap catatan-catatan laporan, metode pengumpulan data, dan teknik analisisnya. Audit trail dalam penelitian ini terbuka bagi siapa saja.

$>$ Expert opinion

Expert opinion dalam validasi yang dilakukan dengan cara meminta tanggapan dari para ahli dan praktisi. Dalam konteks ini, peneliti menempatkan pembimbing tesis sebagai ahli. Untuk keperluan validasi, peneliti akan melakukan wawancara mendalam dan diskusi dengan Pembimbing tesis.

\section{HASIL DAN PEMBAHASAN}

Meningkatkan kompetensi menyusun proposal penelitian tindakan kelas (PTK) guru - guru ekonomi di kabupaten malang

Melalui hasil pengambilan data memang sebagian besar dari angket yang disebar sebanyak 35 angket bagi guru tentang persepsi penyusunan proposal tindakan kelas (PTK) diperoleh hasil bahwa mayoritas (80\%) guru-guru masih belum pernah melakukan kegiatan Penelitian Tindakan Kelas (PTK). Jika ditelusuri lagi ternyata masih banyak guru yang mengalami kesulitan penyusunan Proposal PTK. Hal ini semakin diperparah dengan adanya beban mengajar guru yang terlalu 
banyak karena aktifitas guru terforsir untuk kegiatan proses pembelajaran di dalam kelas. Hasil penelitian tersebut serupa dengan penelitian yang dilakukan oleh (Mediatati.2015) dengan judul "Peningkatan Kompetensi Menyusun Proposal Penelitian Tindakan Kelas Melalui Model Pelatihan Partisipatif dengan Pendampingan Intensif Bagi Guru -guru di SMP Negeri 2 Ampel Kabupaten Booyolali. Dari penelitian tersebut bahwa guru-guru mengalami kesulitan dalam menyusun proposal PTK sehingga melalui pelatihan dan pendampingan intensif maka adanya peningkatan kompetensi guru dalam menyusun proposal PTK dari siklus 1 dan siklus 2. Oleh karena itu sebagai seorang guru harus berupaya meningkatkan kompetensi guru agar kualitas pembelajaran dapat meningkat.

Upaya-upaya guru untuk meningkatkan profesionalismenya tersebut pada akhirnya memerlukan adanya dukungan dari semua pihak yang terkait agar benarbenar terwujud. Mengenai kompetensi, di Indonesia telah ditetapkan sembilan kompetensi yang harus dimiliki oleh guru sebagai instructional leader, yaitu:

a) memiliki kepribadian ideal sebagai guru

b) penguasaan landasan pendidikan

c) menguasai bahan pengajaran

d) kemampuan menyusun program pengajaran

e) kemampuan menilai hasil dan proses belajar mengajar

f) kemampuan menyelenggarakan program bimbingan

g) kemampuan menyelenggarakan administrasi sekolah

h) kemampuan bekerja sama dengan teman sejawat dan masyarakat; dan

i) kemampuan menyelenggarakan penelitian sederhana untuk keperluan pengajaran.

Sebagai pendidik, guru harus professional sebagaimana ditetapkan dalam Undang-undang Sitem Pendiidkan Nasional bab IX pasal 39 ayat 2: Pendidik merupakan tenaga profesional yang bertugas merencanakan dan melaksanakan proses pembelajaran, menilai hasil pembelajaran, melakukan pembimbingan dan pelatihan, serta melakukan penelitian dan pengabdian kepada mayarakat, terutama bagi pendidikan pada perguruan tinggi. Ketentuan ini mencakup tipe macam kegiatan yang harus dilaksanakan oeh guru yaitu pengajaran, penelitan, dan pengabdian masyarakat. Beban ini tidak ada bedanya dengan beban bagi dosen. Tiga macam kegiatan tersebut secara hierarki melambangkan tiga upaya berjenjang dan meluas gerakannya. Pengajaran melambangkan pelaksanaan tugas rutin, penelitian melambangkan upaya pengembangan profesi, sedang pengabdian melambangkan pemberian kontribusi sosial kepada masyarakat akibat prestasi yang dicapai tersebut.

Kemampuan-kemampuan yang selama ini harus dikuasai guru juga akan lebih dituntut aktualisasinya. Misalkan kemampuannya dalam :

- Merencanakan pembelajaran dan merumuskan tujuan.

- Mengelola kegiatan individu.

- Menggunakan multi metode dan memanfaatkan media.

- Berkomunikasi interaktif dengan baik.

- Memotifasi dan memberikan respons.

- Melibatkan siswa dalam beraktifiktas.

- Mengadakan penyesuaian dengan kondisi siswa.

- Melaksanakan dan mengelola pembelajaran.

- Memperbaiki dan mengevaluasi pembelajaran. 
- Menguasai materi pelajaran

- Memberikan bimbingan, berinteraksi dengan sejawat dan bertanggung jawab.

- Mampu melaksanakan penelitian

Sesuai dengan kompetensi yang harus dipenuhi seorang guru menjadi guru yang profesional. Oleh karena itu seorang guru selayaknya harus mampu melakukan penelitian. Seperti yang dikemukakan sebelumnya bahwa dengan memiliki kemampuan meneliti maka seorang guru akan mampu melakukan tugas mendidik secara profesional karena lebih memahami dan mampu menyelesaikan permasalahan yang berkaitan dengan proses pembelajaran.

Efektifitas penyusunan proposal PTK bagi guru-guru Ekonomi di Kabupaten Malang melalui kegiatan pelatihan dan bimbingan intensif.

Melalui kegiatan observasi dan wawancara yang dilakukan pada 5 orang guru yang menjadi informan kunci dalam penelitian ini diperoleh hasil sebagai berikut:

Tabel 1. Efektifitas Penyusunan Proposal PTK sebeum dan sesudah Pelatihan dan Pembimbingan Intensif

\begin{tabular}{|c|c|c|c|}
\hline No & Indikator & \multicolumn{2}{|c|}{ Kondisi } \\
\cline { 3 - 4 } & & Sebelum & Sesudah \\
\hline 1 & Judul & $73 \%$ & $100 \%$ \\
\hline 2 & Latar Belakang Masalah & $80 \%$ & $95 \%$ \\
\hline 3 & Perumusan Masalah & $60 \%$ & $80 \%$ \\
\hline 4 & Tujuan Penelitian & $75 \%$ & $100 \%$ \\
\hline 5 & Manfaat Penelitian & $65 \%$ & $90 \%$ \\
\hline 6 & Kajian Pustaka & $72 \%$ & $95 \%$ \\
\hline 7 & Metode Penelitian & $75 \%$ & $90 \%$ \\
\hline 8 & Jadwal Penelitian & $80 \%$ & $95 \%$ \\
\hline 9 & Daftar Pustaka & $80 \%$ & $95 \%$ \\
\hline 10 & Penggunaan Bahasa & $\mathbf{7 2 , 5 \%}$ & $\mathbf{9 2 \%}$ \\
\hline & Rata-rata Skor & & \\
\hline
\end{tabular}

Berdasarkan tabel 1 di atas dapat diketahui bahwa dengan adanya pelatihan dan pendampingan intensif ada peningkatan skor yang diperoleh pada indikator penyusunan proposal PTK yang sebelum dilakukan pelatihan dan pendampingan intensif hanya sebesar $72,5 \%$ menjadi $92 \%$ sesudah diberikan pelatihan dan pendam-pingan intensif yaitu ada peningkatan sebanyak 19,5\%. Melalui peningkatan skor tersebut dapat dikatakan pelatihan dan pendampingan intensif efektif untuk meningkatkan kemampuan guru dalam menyusun proposal PTK. Hal ini sesuai dengan penelitian yang dilakukan oleh Slameto (2016) dengan judul Penyusunan Proposal Penelitian Tindakan Kelas yang menghasilkan temuan bahwa $65 \%$ peneliti sudah melaksanakan kegiatan PTK, namun hanya $35 \%$ saja masih kurang pengumpulan dan analisis data, pembahasan, membuat kesimpulan dan saran yang disajkan dalam laporan penelitian.

Penelitian yang sejenis juga dilakukan oleh Osnal (2016) dengan judul Upaya Meningkatkan Motivasi dan Kompetensi Guru Kelas 4, Kelas 5, Dan Kelas 6 Dalam Menyusun Proposal PTK Melalui Bimbingan Kelompok di KKG Gugus 6 Kecamatan Sumbermalang Kabupaten Situbondo Semester 2 Tahun Pelajaran 2015/2016 yang menghasilkan temuan strategi bimbingan kelompok dapat 
meningkatkan motivasi dan kompetensi guru-guru kelas 4, kelas 5, kelas 6 di Gugus 6 dalam menyusun proposal Penelitian Tindakan Kelas.

\section{KESIMPULAN}

Dari beberapa uraian yang sudah dipaparkan dapat disimpulkan sebagai berikut: 1) Mayoritas (80\%) guru - guru masih belum pernah melakukan kegiatan Penelitian Tindakan Kelas (PTK). Jika ditelusuri lagi ternyata masih banyak guru yang mengalami kesulitan penyusunan Proposal PTK; 2) Melalui peningkatan skor tersebut dapat dikatakan pelatihan dan pendampingan intensif efektif untuk meningkatkan kemampuan guru dalam menyusun proposal PTK karena ada peningkatan $19,5 \%$ (72,5\% sebelum dan $92 \%$ sesudah).

Saran yang diberikan dalam kegiatan ini yaitu: 1) Bagi guru ekonomi SMA/MA seharusnya dapat mengapli-kasikan penelitian tindakan kelas dalam proses pembelajaran sesuai dengan temuan pada saat proses pembelajaran di kelas; 2) Guru-guru dapat mengupgrade ilmu ekonomi yang terbaru sesuai dengan bidang keilmuan masing-masing dengan cara terlibat aktif dalam kegiatan pengabdian yang dilakukan oleh civitas perguruan tinggi; 3) Kegiatan pengabdian yang dilakukan sehendaknya dapat dikembangkan menjadi kegiatan penelitian kelompok yang melibatkan dosen-dosen dan guru-guru secara bersama dengan mengangkat isu/masalah yang up to date.

\section{DAFTAR PUSTAKA}

Ani Widayati (2008) Penelitian Tindakan Kelas. Jurnal Pendidikan Akuntansi Indonesia. VI(1), 87-93,

Creswell, John W(2015). Penelitian kualitatif \& Desain Riset Memimilih diantara lima Pendekatan. Yogyakarta:Pustaka Pelajar.

Depdiknas (2003) Undang-undang RI No.20 tahun 2003.tentang Sistem Pendidikan Nasional, Jakarta: Sinar Grafika.

(2005)Undang-UndangRepublik Indonesia Nomor 14 Tahun 2005 tentang Guru dan Dosen. Jakarta: Sinar Garafika

Jalal, Fasli \& Dedi Supriadi (2001) Reformasi Pendidikan Dalam Konteks Otonomi Daerah, Yogyakarta: Adicita Karya Nusa.

Mediatati, Nani (2015, November) Peningkatan Kompetensi Menyusun Proposal Penelitian Tindakan Kelas Melalui Model Pelatihan Partisipatif Dengan Pendampingan Intensif Bagi Guru Guru Di SMP Negeri 2 Ampel Kabupaten Boyolali. Prosiding Seminar Nasional Pendidikan Ekonomi \& Bisnis Fakultas Keguruan dan Ilmu Pendidikan Universitas Sebelas Maret Surakarta

Osnal (2016) Upaya Meningkatkan Motivasi Dan Kompetensi Guru Kelas 4, Kelas

5, Dan Kelas 6 Dalam Menyusun Proposal Ptk Melalui Bimbingan Kelompok Di KKG Gugus 6 Kecamatan Sumbermalang Kabupaten 
Situbondo Semester 2 Tahun Pelajaran 2015/2016. Artikel tidak diterbitkan

Slameto (2016) Penyusunan Proposal Penelitian Tindakan Kelas. Artikel tidak diterbitkan

Sukanti (2008) Meningkatkan Kompetensi Guru Melalui Pelaksanaan Penelitian Tindakan Kelas.Jurnal Pendidikan Akuntansi Indonesia. VI(1), 1-11 